\title{
Factors affecting low back pain complaint to workers in gravity casting area automotive industry Indonesia
}

\author{
Siti Rachmawati ${ }^{1}$, Zulfia Muthia ${ }^{2}$ \\ ${ }^{1}$ Department Hygiene and Occupational Health and Safety, Sebelas Maret of University
}

\begin{abstract}
Lower back pain (LBP), which is also called lower back pain, is the most experienced reality, the incidence of lower back pain occurs significantly in age, sex, occupation, social status, or education/knowledge level. This also causes more than $70 \%$ of people in their lives have reported low back pain. This study aims to determine the factors that affect the low back pain in Area Gravity Casting PT. Akebono Brake Astra Indonesia. The type of this research is analytic observational research using cross sectional method. Location of research in the field of gravity casting. A sample of 30 workers. The sampling technique used is total sampling. The statistical tests used to determine lower back pain are Spearman and Odds Ratio for risk factors. The results showed that age factor, length of service, body mass index, exercise habit and smoking habit did not affect the lower back pain response with $p>0,05$ while standing attitude had significant influence with result $\mathrm{p}=0,03$ and $\mathrm{OR} 18,667$.
\end{abstract}

Keywords : Factors, Complaint, Low Back Pain

\section{BACKGROUND}

Low back pain (LBP) is the most common complaints experienced by workers, low back pain occurrence occurs thoroughly regardless of age, sex, occupation, social status, or education/knowledge level. This also resulted in more than $70 \%$ of people in his life had experienced low back pain [15]. The prevalence of Low Back Pain occurrences in working communities, especially workers employed by means of production, was reported at $39 \%$, while in static workers had a prevalence of low back pain of $18.3 \%$ [2] . The National Safety Council reports that the highest frequency of work-related illness is lower back pain that is $22 \%$ of $1,700,000$ cases and among musculoskeletal system complaints, which many workers experience is low back pain [12].

Low back pain events in the working community are caused by ergonomic factors in the workplace. One of these ergonomic factors is the result of work attitudes. The attitude that many workers encountered in the industry, especially the retail industry is the attitude of standing work. Working attitude done monotonously with long working time will lead to feelings of discomfort even fatigue. Muscles used for work will be taut continuously and cause a feeling of stiffness (dull ache). The body can tolerate only long standing postures in one position for only 20 minutes. If more than that limit, slowly will arise discomfort in the lower back area[10].

Low back pain is a chronic complaint that takes a long time to develop and manifest. So the longer a person works or exposed to risk factors, the greater the risk of low back pain symptoms or lower back pain [8]. Previous research on Low Back Pain has been done by Sitepu, M., Sinaga, MM, Kalsum as a result of the type of lifting and spraying work on citrus farmers in the village of Dokan, Karo District, which is shown by significance value $p=0.010$ and $p=0.042$. The study proves that to a significant relationship between standing position and Low Back Pain complaint [9].

Many factors can cause Low Back Pain, but generally the factors that cause Low Back Pain is divided into three factors, namely work factors, individual factors, and environmental factors. Individual factors related to work period, age, length of work, gender, work position, smoking habits, exercise habits, obesity, habitual alcohol consumption and others. While that includes environmental factors such as vibrations exposed to a person's body continuously or temperature extremes. Job factors that could lead to Low Back Pain include doing repetitive work, labor-intensive work, and static work [6].

Low Back Pain (LBP) can be caused by a muscle strain. These LBP types vary, can be dull or sharp, and

\footnotetext{
*Corresponding author : siti.rachmawati@ staff.uns.ac.id
} 


\begin{tabular}{|l|c|c|}
\hline LBP complaints & Amount & $\begin{array}{c}\text { precentage } \\
(\mathbf{\%})\end{array}$ \\
\hline $\begin{array}{l}\text { Minimal } \\
\text { Disability }\end{array}$ & 22 & $73,3 \%$ \\
\hline $\begin{array}{l}\text { Moderate } \\
\text { Disability }\end{array}$ & 7 & $23,3 \%$ \\
\hline Severe Disability & 0 & $0 \%$ \\
\hline Crippled & 1 & $3,3 \%$ \\
\hline Bed Bound & 0 & $0 \%$ \\
\hline Total & $\mathbf{3 0}$ & $\mathbf{1 0 0 \%}$ \\
\hline
\end{tabular}

may get worse in a sitting position, standing, walking, or other movements. Stretch out can usually help improve things. Sometimes the spinal disc may protrude, causing pressure on the nerves that exist between the spine. Signs of pressure on the nerves are pain that spreads to the feet, tingling, and numbness. More rarely, it can lead to bowel or bladder control. Arthritis or degeneration of the vertebral bone can also cause LBP [5].

PT. Akebono Brake Astra Indonesia is an automotive company producing brake system components that produce drum brakes and disc brakes for cars and master cylinders and disc brakes for motorcycles. Workers in the process of melting in the area of gravity casting have low back pain complaints (lower back pain) as many as 5 people and some workers have done work rotation due to the complaint [9]. Melting process is the process of ingot and scrap ingredients into liquid aluminum which becomes the raw material for the formation of body caliper and master cylinder products. Working process in the melting part of the workers lifting ingot 16 stems and scrap 1 can of $15-18 \mathrm{~kg}$ average done as much as 16 times for one time melting. The process of smelting is done continuously stirring for 2 hours by the worker.

In economic planning and urban areas, industrial areas are intensive land use and economic activities related to manufacturing and the production of Industrial Establishment certainly has an impact, both on the environment and social environment. For the environment the industry brings many negative impacts such as water pollution, air pollution and so on. For example Pollution by heavy industrial factories causes acid rain that destroys the forest and so on. As much as possible for the social environment can reduce the unemployment rate, improve the welfare of the community around the industrial area and so on.

\section{METHODS}

This research uses Observational Analytical Research with Cross Sectional approach this is because the cause and effect variable that happened in the research object is measured or collected in the same time and done in same situation [13]. The research was conducted in the process of melting area gravity casting PT. Akebono Brake Astra Indonesia. The sample used is 30 workers who work in melting process. The sampling technique used is total sampling method.

\section{RESULT AND DISCUSSION}

\subsection{Univariate Analysis}

Table 1. Results of Low Back Pain Complaint Assessment

Based on the above table, the low back pain complaint is known that the workers who have complaints in the category of minimum disability category amounted to 22 people labor, moderate disability amounted to 7 people labor. So the largest distribution is in the category of minimal disability with the number of 22 workers. Assessment of low back pain complaints using the Indonesian version of the Modified Oswestry Low Back Pain Disability Questionnaire (ODI) and used in a study conducted by Wayudin [14].

Table 2. Frequency Distribution Based on Individual Factors (Age, Work Period, Smoking Habit, Sports Habits, Body Age Index, Standing Posture)

\begin{tabular}{|c|c|c|c|c|}
\hline No & Variable & Category & $\begin{array}{c}\text { amount } \\
\text { (n) }\end{array}$ & $\%$ \\
\hline \multirow[t]{3}{*}{1} & \multirow[t]{3}{*}{ Age } & $21-30$ & 13 & \\
\hline & & $31-40$ & 16 & \\
\hline & & $41-50$ & 1 & \\
\hline \multirow[t]{4}{*}{2} & \multirow{4}{*}{$\begin{array}{l}\text { Work } \\
\text { Period }\end{array}$} & $1-5$ & 1 & $3,3 \%$ \\
\hline & & $6-10$ & 16 & $53,3 \%$ \\
\hline & & $11-15$ & 8 & $26,7 \%$ \\
\hline & & $16-20$ & 5 & $16,7 \%$ \\
\hline \multirow[t]{5}{*}{3} & \multirow{5}{*}{$\begin{array}{l}\text { Body } \\
\text { Age } \\
\text { Index }\end{array}$} & Normal & 12 & $40 \%$ \\
\hline & & Gemuk & 15 & $50 \%$ \\
\hline & & $\begin{array}{l}\text { Obesitas } \\
\text { Lv } 1\end{array}$ & 3 & $10 \%$ \\
\hline & & $\begin{array}{l}\text { Obesitas } \\
\text { Lv } 2\end{array}$ & 0 & $0 \%$ \\
\hline & & $\begin{array}{l}\text { Obesitas } \\
\text { Lv } 3\end{array}$ & 0 & $0 \%$ \\
\hline \multirow[t]{2}{*}{4} & \multirow[t]{2}{*}{$\begin{array}{l}\text { Smoking } \\
\text { Habits }\end{array}$} & $\begin{array}{l}\text { Tidak } \\
\text { Merokok }\end{array}$ & 17 & $56,7 \%$ \\
\hline & & Merokok & 13 & $43,3 \%$ \\
\hline \multirow[t]{2}{*}{5} & \multirow[t]{2}{*}{$\begin{array}{l}\text { Sports } \\
\text { Habits }\end{array}$} & $\begin{array}{l}\text { Tidak } \\
\text { Olahraga }\end{array}$ & 14 & $46,7 \%$ \\
\hline & & Olahraga & 16 & $53,3 \%$ \\
\hline \multirow[t]{5}{*}{6} & \multirow{5}{*}{$\begin{array}{l}\text { Assessm } \\
\text { ent of } \\
\text { Working } \\
\text { Stance } \\
\text { Based on } \\
\text { REBA } \\
\text { Method }\end{array}$} & $\begin{array}{l}\text { The risk } \\
\text { category is } \\
\text { very low }\end{array}$ & 0 & $0 \%$ \\
\hline & & $\begin{array}{l}\text { Low risk } \\
\text { category }\end{array}$ & 0 & $0 \%$ \\
\hline & & $\begin{array}{l}\text { Medium } \\
\text { risk } \\
\text { category }\end{array}$ & 0 & $0 \%$ \\
\hline & & $\begin{array}{l}\text { High risk } \\
\text { category }\end{array}$ & 17 & $56,7 \%$ \\
\hline & & $\begin{array}{l}\text { The risk } \\
\text { category is } \\
\text { very high }\end{array}$ & 13 & $43,3 \%$ \\
\hline
\end{tabular}

Based on the above table it is known that from 30 respondents, there are most respondents have vulnerable 
age 31-40 years. Body Age Index on respondents in the fat category as many as 15 . Respondents who have the habit of smoking as much as 14 . Respondents who have exercise habits as much as 16 respondents. Respondent based on the assessment of work posture standing in the high risk category (required immediate action) as many as 17 respondents and respondents who are categorized very high risk (requires action as soon as possible) as much as 13 respondents.

\subsection{Bivariate Analysis}

Table 3. Results of Effects of Individual Factors with Low Back Pain Complaints

\begin{tabular}{|c|c|c|c|}
\hline \multirow[t]{2}{*}{ Variable } & \multicolumn{2}{|c|}{ LBP complaints } & \multirow[t]{2}{*}{ p-value } \\
\hline & Yes & No & \\
\hline \multicolumn{3}{|l|}{ Age } & \multirow{6}{*}{0.473} \\
\hline $21-25$ & 0 & 1 & \\
\hline $26-30$ & 3 & 9 & \\
\hline $31-35$ & 2 & 7 & \\
\hline $36-40$ & 3 & 4 & \\
\hline $41-45$ & 0 & 1 & \\
\hline \multicolumn{3}{|l|}{ Work Period } & \multirow{5}{*}{0.630} \\
\hline $1-5$ & 0 & 1 & \\
\hline $6-10$ & 4 & 12 & \\
\hline $11-15$ & 3 & 5 & \\
\hline $16-20$ & 1 & 4 & \\
\hline \multicolumn{3}{|c|}{ Body Mass Index } & \multirow{4}{*}{0.411} \\
\hline Normal & 4 & 8 & \\
\hline Gemuk & 4 & 11 & \\
\hline $\begin{array}{l}\text { obesitas level } \\
1\end{array}$ & 0 & 3 & \\
\hline \multicolumn{3}{|l|}{ Sports Habits } & \multirow{3}{*}{1.000} \\
\hline $\begin{array}{l}\text { tidak } \\
\text { olahraga }\end{array}$ & 4 & 10 & \\
\hline Olahraga & 4 & 12 & \\
\hline \multicolumn{3}{|c|}{ Smoking Habits } & \multirow{3}{*}{0.668} \\
\hline $\begin{array}{l}\text { tidak } \\
\text { merokok }\end{array}$ & 5 & 12 & \\
\hline Merokok & 3 & 10 & \\
\hline \multicolumn{3}{|c|}{$\begin{array}{l}\text { Assessment of Working Stance Based on } \\
\text { REBA Method }\end{array}$} & \multirow{6}{*}{0.002} \\
\hline $\begin{array}{l}\text { The risk } \\
\text { category is } \\
\text { very low }\end{array}$ & 0 & 0 & \\
\hline $\begin{array}{l}\text { Low risk } \\
\text { category }\end{array}$ & 0 & 0 & \\
\hline $\begin{array}{l}\text { Medium risk } \\
\text { category }\end{array}$ & 0 & 0 & \\
\hline $\begin{array}{l}\text { High risk } \\
\text { category }\end{array}$ & 1 & 16 & \\
\hline $\begin{array}{l}\text { The risk } \\
\text { category is } \\
\text { very high }\end{array}$ & 7 & 6 & \\
\hline
\end{tabular}

Effect of age with low back pain complaints based on bivariate analysis in table 3 can be seen that static test shows $\mathrm{p}$ value 0.473 which means age in worker melting area gravity casting does not have a significant effect on low back pain complaints (pain lower back) experienced by workers and those who do not experience complaints. This is in line with research conducted by Sitepu, M., Sinaga, M.M., Kalsum [9] which states that the age of the driver of public transportation who experience low back pain complaints with a $\mathrm{p}$ value of 0.485 .

The influence of working period with low back pain complaints based on bivariate analysis in table 3 can be seen that static test shows $\mathrm{p}$ value 0.630 which means the working period in the worker of melting area gravity casting has no significant effect to low back pain (lower back pain) experienced by workers and those who did not experience a complaint. This is in line with Ikrimah's [7] study which says that the working period has no significant relationship with low back pain complaints with $\mathrm{p}$ value of 0.313 .

The effect of body mass index with low back pain complaints based on bivariate analysis in table 3 can be seen that static test shows $\mathrm{p}$ value of 0.411 which means body index on worker of melting area gravity casting have no significant effect to low complaint back pain experienced by workers and those who do not experience a complaint. This is not in accordance with research conducted by Indri and Legiran [6] which shows that $\mathrm{p}$ value of 0.04 means $p<0.05$ concluded there is a relationship between body mass index with low back pain.

The influence of exercise habits with low back pain complaints based on bivariate analysis in table 3 can be seen that static test shows the value of $p$ value 1,000 which means exercise habits on the worker melting area gravity casting does not have significant effect on low back pain complaints (lower back pain) experienced by workers and those who did not experience a complaint. This is in accordance with research conducted Basuki [1] that sports activities do not specifically cause low back pain.

The influence of smoking habit with low back pain complaints based on bivariate analysis in table 3 can be seen that static test shows the value of $p$ value 0.668 which means the smoking habit in the worker melting area gravity casting has no significant effect on low back pain complaints (lower back pain) experienced by workers and those who did not experience a complaint. This is in accordance with research conducted Basuki [1] which shows that there is no significant relationship between the incidence of low back pain with smoking habit $(\mathrm{p}$ value $=0.723$ ).

In this study risk factors that can affect low back pain complaints such as age, work period, body mass index, exercise habits and smoking habits do not contribute to low back pain complaints. Where that indirectly gives an indication that these variables are not the cause of the emergence of low back pain complaints on workers in the process of melting area gravity casting PT. Akebono Brake Astra Indonesia.

The influence of work posture stands with low back pain complaints based on bivariate analysis in table 3 can be seen that static test shows the value of $p$ value 0.002 which means work posture at work melting area gravity casting effect on complaints low back pain (back 
pain under). This is in line with research conducted by Susanti, Hartiyah and Kuntowato [10] as a result of long standing position on the cashier worker shown with significance value $p=0,013$. The study proves that to a significant relationship between standing position with low back pain complaints.

Body positions that deviate significantly from normal position while doing the work can cause local mechanical stress in muscles, ligaments, and joints. This results in injuries to the neck, spine, shoulders, wrists, and others. Unnatural work attitude causes the body part to move away from its natural position. The further the position of the body part of the center of gravity, the higher the occurrence of skeletal muscle complaints. Work attitude is unnatural in general due to workers 'non-conformity with workers' ability [4].

Based on this research, the work posture used in melting area gravity is standing where the work process of the workers is to lift the metal ingot and scrab average weighing $25 \mathrm{~kg}$ as much as 12 times to be merged into aluminum. Workers are required to stand to stir during the melting process. The work process is done for 8 hours of work. The intensity of long standing positions and repeated bending motions to lift the ingot and scrab metal have an effect on the pain on the lower back (low back pain).

Work standing posture is assessed using the REBA method. The REBA method is used to assess posture work at risk associated with low back pain complaints or disorders of Musculuskeletal Disorders (MSDs). The application of this method is aimed at preventing the risk of position-related injuries, particularly in the musculoskeletal muscle system. Therefore, this method can be useful for risk prevention and can be a reminder that there are inappropriate working conditions in the workplace [11].

\section{REFERENCES}

1. K. Basuki. J Prom Kes Indonesia. 42:115-21. (2009)

2. A. Delitto. et al. J Orthopaedic \& Sports Physical Therapy, pp. 42(4):A1-A57. (2012)

3. F. A. Rifqy., (Faktor - faktor yang Berhubungan dengan Musculoskeletal Disorders (MSDs) pada Pengrajin sepatu di Perkampungan Industri Kecil Penggilingan Kecamatan Cakung. Fakultas Kedokteran dan Ilmu Kesehatan Univeristas Islam Negeri Syarif Hidayatullah Jakarta, 2013)

4. E. Grandjean,. Fitting The Task To The Man, $\left(4^{\text {th }}\right.$ edt. Taylor \& Francis Inc.London 1993).

5. D.M. Goodman, A.E. Burke, E.H. Livingston. JAMA. ;16:309. (2013)

6. S.S. Indri, Legiran. J Keperawatan. 1:2-4 (2014)

7. N. Ikrimah.. (Faktor-Faktor yang Berhubungan dengan Keluhan MSDs pada pekerja konveksi sektor usaha informal di Wilayah Ketapang Cipondoh Tangerang, 2010)

8. K. Trimunggara., (Faktor-faktor yang mempengaruhi keluhan low back pain pada kegiatan mengemudi tim
The results of the REBA method assessment in Table 3 show that workers in the melting area gravity casting process fall into the high risk category (immediate action required) with a final score of 8-10 of 17 workers and a very high risk category (action required as soon as possible) with final score $1-115$ as many as 13 workers. Ikrimah (2009) explains under Canadian Center for Occupational Health and Safety. Working activities such as repetitive work, or jobs with abnormal postures are what can cause the appearance of disorders of Musculuskeletal Disorders (MSDs), whose pain can be felt during work or when not working.

\section{CONCLUSION}

Based on the research conducted there is the effect of standing posture with low back pain complaints on workers melting area gravity casting process at PT. Akebono Brake Astra Indonesia with $\mathrm{p}$ value $=0,002$. Has an Odds Ratio of 18,667 which means that workers with wrong standing posture are more at risk 18,667 fold lower pains complaints than workers with correct work postures.

Suggestions should provide proper socialization of work postures such as lifting and transporting goods so that low back pain complaints can be minimized. Companies should rehabilitate workers who experience low back pain complaints. Companies should provide several programs for the management of waste produced by solid, liquid and air waste as an effort to support government programs, namely to become an environmentally sound industry and Sustainable Development Goals (SDGs), namely Climate Action.

ekspedisi PT. Enseval Putera Megatrading Jakarta, 2010)

9. M. Sitepu, ,M.M. Sinaga, Kalsum. (Faktor-Faktor Yang Berhubungan Dengan Keluhan Low Back Pain (Nyeri Punggung Bawah) Pada Supir Angkot Rahayu Medan Ceria 103 Di Kota Medan, 2015)

10. Susanti, Hartiyah, \& Kuntowato. J Pena Medika, pp. 60-70 (2015)

11. Tarwaka. Ergonomi industri. (Harapan Press, 2015)

12. T.S. Waters, V. P. Anderson. (Manual Materials Handling. Edited By Bharattacharya, A \& McGlothin, J.D.. Occupational Ergonomics Theory and Applications, 1996)

13. S. Notoatmodjo. Metodologi Penelitian Kesehatan. Rineka Cipta (2010)

14. Wahyuddin. Adaptasi Lintas Budaya Modifikasi Kuesioner Disabilitas Untuk Nyeri Punggung Bawah (Modified Oswestry Low Back Pain Disability Questionnare/ODI) Versi Indonesia, 2016)

15. Anderson, E. T., 2007. Buku Ajar Keperawatan Komunitas : Teori dan Praktek. Jakarta: EGC. 